\title{
Osteoprotegerin rich tumor microenvironment: implications in breast cancer
}

\author{
Sudeshna Goswami ${ }^{1}$ and Neelam Sharma-Walia ${ }^{1}$ \\ ${ }^{1}$ H. M. Bligh Cancer Research Laboratories, Department of Microbiology and Immunology, Chicago Medical School, Rosalind \\ Franklin University of Medicine and Science, North Chicago, Illinois, USA \\ Correspondence to: Neelam Sharma-Walia, email: neelam.sharma-walia@rosalindfranklin.edu \\ Keywords: osteoprotegerin, NF-kB, COX-2, PGE2, FASN
}

Received: February 23, $2016 \quad$ Accepted: March 31, 2016

Published: April 08, 2016

\section{ABSTRACT}

Osteoprotegerin (OPG) is a soluble decoy receptor for tumor necrosis factor (TNF)-related apoptosis inducing ligand (TRAIL). It belongs to the tumor necrosis factor receptor superfamily (TNFRSF). OPG was initially discovered to contribute to homeostasis of bone turnover due to its capability of binding to receptor activator of nuclear factor-kappaB (NF-kB). However, apart from bone turnover, OPG plays important and diverse role(s) in many biological functions. Besides having antiosteoclastic activity, OPG is thought to exert a protective anti-apoptotic action in OPGexpressing tumors by overcoming the physiologic mechanism of tumor surveillance exerted by TRAIL. Along with inhibiting TRAIL induced apoptosis, it can induce proliferation by binding to various cell surface receptors and thus turning on the canonical cell survival and proliferative pathways. OPG also induces angiogenesis, one of the hallmarks of cancer, thus facilitating tumor growth. Recently, the understanding of OPG and its different roles has been augmented substantially. This review is aimed at providing a very informative overview as to how OPG affects cancer progression especially breast cancer.

\section{INTRODUCTION}

\section{BREAST CANCER}

At present, one in eight women in the United States will develop breast cancer [1]. Recent advances in breast cancer detection and treatment have decreased the mortality rate of breast cancer [1] but the success of treatment relies largely on detection of the disease at early stages [1]. A lack of knowledge regarding the molecular mechanisms underlying breast tumor progression to invasive and then metastatic disease limits the ability to treat advanced disease. The identification of factors that promote metastasis is essential for the development of new breast cancer therapies and a further reduction in breast cancer mortality [2]. Inflammatory breast cancer (IBC) is a highly aggressive, angioinvasive, and a highly metastatic form of breast cancer. IBC is associated with a high incidence of early nodal and systemic spread. Systemic chemotherapy, adjuvant therapy, surgery and radiation have not improved disease prognosis or overall survival of IBC patients [3, 4].

\section{TUMOR MICROENVIRONMENT}

The tumor microenvironment (TME) is the cellular environment in which the tumor exists and provides its niche for growth, progression, survival and evolution. The normal microenvironment provides crucial signaling to maintain appropriate tissue architecture, inhibit cell growth and suppress the malignant phenotype, and acts as a barrier to tumorigenesis [5]. Incorrect signals from TME can destabilize tissue homeostasis, initiate, promote, and push normal cells to malignant phenotype [5]. The TME is highly complex and dynamic, and includes blood vessels, immune cells, inflammatory cells, and components of the extracellular-matrix (ECM). TME is also rich in various cytokines, chemokines, ECM proteins, growth and angiogenic factors involved in autocrine but also 
paracrine cell signaling. The field of TME has expanded our understanding of cancer as more than a single factor driven disease. Rather, cancer biology involves complex reciprocal interaction and co-evolution between cancer cells and host stromal cells, interplay of soluble growth factors and chemokines as the key mediators involved in oncogenic signaling pathways of tumors. The list of anti-cancer therapies and clinical trials based on the role of the microenvironment in various types of cancers has grown long and it includes endostatin, Bevacizumab (Avastin), MK-2416, Anastroazole, Bay 43-9006, DX2400, Celecoxib, and PG545 etc. [5]. The majority of these are multikinase inhibitors blocking tumor cell growth pathways such as BRAF, Bcr-Abl, c-Kit, vascular endothelial growth factor receptor-1 (VEGFR-1), VEGFR-2, VEGFR-3, PDGFR and colony-stimulating factor-1 receptor [5]. Proteomic landscape of the breast cancer TME includes diverse factors involved in tumor growth, proliferation, metastasis, vascularity, evading cell death pathways and host immune system. In our previous study we demonstrated that inflammatory and invasive breast cancer TME is rich in OPG, chemokines such as urokinase-type plasminogen activator receptor (UPAR), Oncostatin M (OSM), IL-6 and GRO- $\alpha$ [6]. Here, we focus only on osteoprotegerin (OPG) as one of the factors present in the TME of inflammatory and invasive breast cancer cell lines, and discuss how it multitasks various functions to drive tumorigenesis.

\section{OSTEOPROTEGERIN (OPG)}

OPG was first identified by sequence homology to the tumor necrosis factor receptor (TNFR) family during a rat intestine cDNA sequencing project and was named based on its function (Latin: os bone, protegere to protect) [7]. OPG was independently discovered and alternatively named osteoclastogenesis inhibitory factor (OCIF) [8], TR1 [9], and follicular DC-derived receptor-1 (FDCR-1) [10], which are found to be identical to OPG. The human OPG gene is located at chromosome 8q2324 and is composed of 401 amino acids [11]. The OPG protein comprises 401 amino acids of which 21 form a signal peptide [12] (Figure 1). Human and murine OPG consist of four cysteine rich pseudo repeats located in the $\mathrm{N}$-terminal, two death domains, and a heparin-binding site located in the C-terminus and a 21 amino acid signal peptide [11]. Signal peptide is cleaved to generate a mature form of 380 amino acids (Figure 1). At the $\mathrm{N}$ terminus, there are four domains (D1-D4), which have cysteine-rich TNF receptor homologous motifs [12]. These motifs are required and are sufficient for binding to its major target, the receptor activator of nuclear factor (NFKB) ligand (RANKL), and for inhibiting osteoclastic differentiation and activation [12]. At the $\mathrm{C}$ terminus, there are tandem death-domain homologous regions (D5 and D6) followed by a heparin-binding site (D7) [12] (Figure 1). More specifically at position 400 , there is a cysteine required for homodimerization of the molecule (Figure 1). OPG is

\section{Inhibition of osteoclast formation Cytotoxicity domain (when fused with Fas)}

(RANKL binding domain)
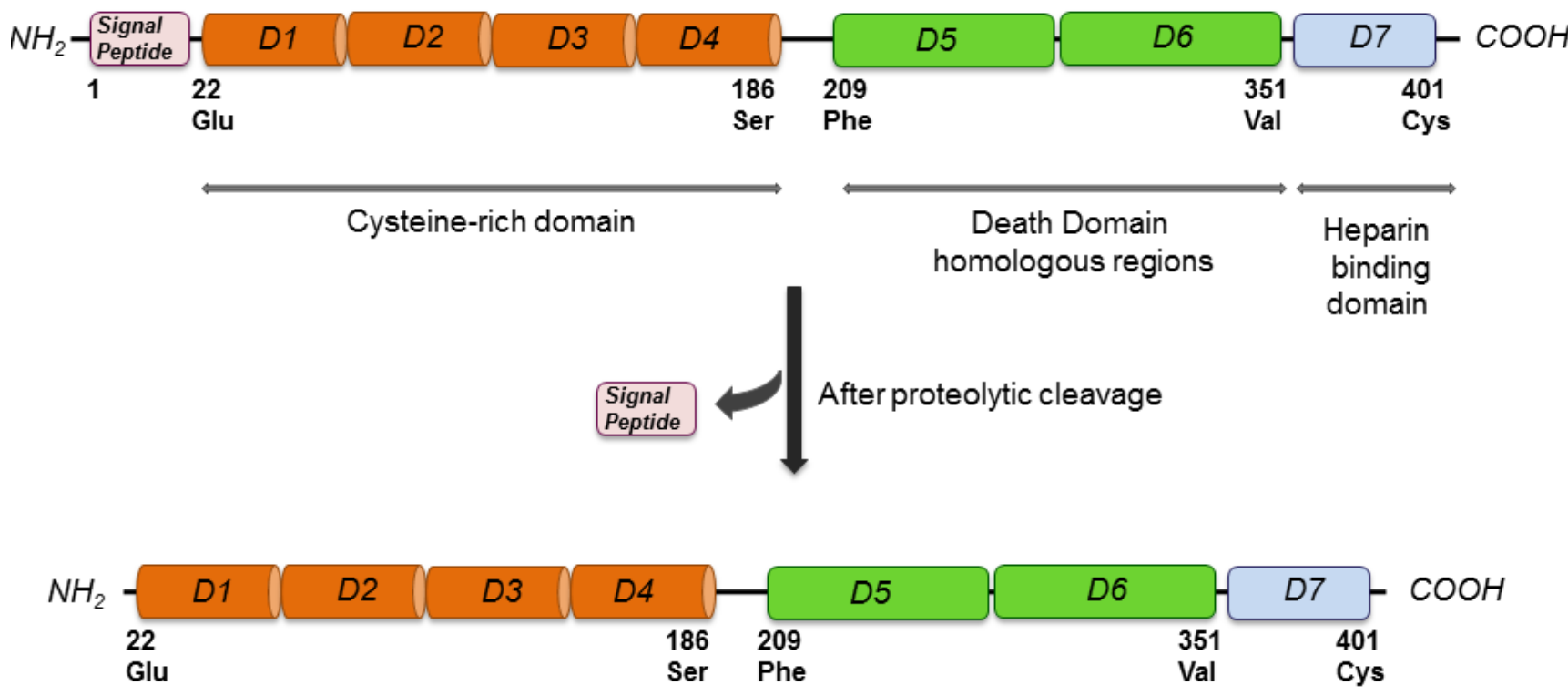

Figure 1: Molecular structure of OPG highlighting its different binding and functional domains. 
a secreted protein with no transmembrane or cytoplasmic domain, and is produced as a monomer $(55-62 \mathrm{kDa})$ that undergoes homodimerization $[11,12]$. OPG is secreted as a disulfide-linked homodimeric glycoprotein with four or five potential glycosylation sites, generating a mature form of OPG of 110-120 kDa [12]. The dimeric form of the protein exhibits a greater affinity for RANKL and a higher heparin-binding capacity than the monomeric form. The heparin binding site (D7) of OPG facilitates its binding to cell membrane-associated heparan sulfates. Heparan sulfates are expressed on the cell surface as heparan sulfate proteoglycans (HSPGs), and are involved in cell signaling, controlling cell behavior, actin cytoskeleton regulation, cell adhesion, and cell migration [13]. For biological use, D7, D5, and D6 are removed, and the remaining amino acids 22-194 OPG peptide is fused to the Fc domain of human IgG1 (OPG-Fc), which maintains the potent dimeric nature of full-length OPG and exhibits a significantly increased circulating half-life $[12,14]$. OPG is highly expressed in the adult lung, heart, kidney, liver, thymus, lymph nodes and bone marrow [11].OPG is synthesized by several cells including stromal cells, osteoblasts, vascular smooth muscle cells, B lymphocytes, and articular chondrocytes [11].

\section{OPG AND BREAST CANCER}

One of the first studies to characterize OPG revealed its expression in two human breast cancer cell lines, MDA-MB-436 and MCF-7 [15]. Further studies have confirmed the expression of OPG in breast cancer cell lines and tissues. The MCF-7, MDA-MB-231 and T47D human breast cancer cells lines were tested for OPG mRNA expression by real time PCR alongside 12 primary breast tumor samples [16]. OPG is expressed in $40 \%$ of breast cancers but not in normal breast tissue, and the TRAIL sensitive breast cancer cell line MDA-MB-436 produces sufficient levels of OPG to inhibit TRAILinduced apoptosis in vitro [17]. OPG mRNA expression is upregulated in human breast cancer cell lines and tumor samples. The expression pattern of OPG was examined by immunohistochemistry in 400 invasive breast cancer tissue samples [18]. It was found that $40 \%$ of the invasive breast tumors expressed OPG with expression confined to tumor cells. It should be noted that the expression of OPG by tumor cells is not limited to the cancer cell expressing it but it has tremendous paracrine effect on the neighboring healthy cells.

Our study [6] for the first time, revealed that OPG is secreted and expressed at very high levels from the SUM1315MO2 invasive breast cancer cell line, as well as the SUM149PT and SUM190PT inflammatory breast cancer cell lines. OPG was secreted at a concentration of $500 \mathrm{pg} / \mathrm{ml}$ and $1100 \mathrm{pg} / \mathrm{ml}$ from SUM1315MO2 and SUM149PT, respectively [6]. Our study [6] demonstrated specific OPG staining in inflammatory breast cancer patient tumor sections apart from invasive breast cancer tumor sections which has been reported previously [18]. Heavy secretion of OPG led us to hypothesize that OPG directly or indirectly might be involved in inducing various oncogenic factors and thus contributing to the severity of the disease.

Breast cancer tissue is a heterogeneous system, mainly composed of tumor epithelial cells and stromal cells. The crosstalk between malignant and nonmalignant cells takes place in the breast TME at the primary site. This interaction, which can be via cytokines and chemokines, plays a major role in the various steps of breast cancer progression [19-23]. Therefore, the bidirectional crosstalk between the breast cancer cells and the tumor microenvironment components including immune cells, mesenchymal stem cells (MSCs), tumor associated fibroblasts (TAFs), fibroblasts, tumor vasculature, and extracellular matrix play vital roles in shaping tumor progression, aggressiveness and the bulk of the disease. This interaction, mainly driven by soluble secreted factors allows tumor cells to modify the stroma via tissue remodeling and gene expression and vice versa [22]. Therefore, defining the nature of the signals exchanged between the tumor microenvironment and the tumor cells should provide insights into how breast cancer develops and progresses, and may help to reveal therapeutic modalities based on intercepting the tumorstroma crosstalk. Recruitment of the different components, including the MSCs and TAFs, is mediated by binding of different chemical messengers such as the TRAIL, TNF- $\alpha$, TGF- $\beta$, chemokine (C-C motif) ligands, IL6, and platelet derived growth factor (PDGF) to their respective receptors. The MSCs are known to increase tumor progression, which is mediated by different cytokines such as OPG, TRAIL, IL-6, IL-8, CCL-5, CCL-2, and RANKL. These factors are known to increase the breast cancer development by regulating patient survival, bypassing apoptosis, invasion, migration and tumor angiogenesis [24]. OPG, TRAIL, and RANKL are significantly higher in tumor epithelial cells from patients with breast cancer than in epithelial cells of non-neoplastic breast tissues [25]. Moreover, the expression of OPG, TRAIL, RANKL, and RANK was significantly higher in spindle-shaped stromal cells from patients with breast cancer than in nonneoplastic tissue stromal cells [25].

\section{ROLE OF OPG IN METASTASIS}

Metastasis is an intricate multistep process, which is closely associated with worse prognosis of patients with tumors, and spread of the tumor. For example, bone metastasis is considered lethal and is an active area of research for potential therapeutic developments targeting bone cancer metastases. Bone metastases occur in more than $70 \%$ of breast cancer patients and cause severe skeletal complications such as fractures, spinal cord 
compression, bone pain, and hypercalcemia [26]. Patients with estrogen receptor-positive $(\mathrm{ER}+)$ breast cancer constitute a major clinical population who are at risk for bone metastases [26]. More than 50\% of primary breast cancer cells express OPG and RANK, while RANKL could be detected only in 14-60\% [25]. OPG is one of the important players of the OPG/ receptor activator of nuclear factor kappa-B (RANK)/RANK ligand (RANKL) triad (Figure 2), and is a secreted member of the TNFR superfamily of proteins [27]. OPG functions as an endogenous antagonist receptor that prevents the biological effects of RANKL, both membranous and soluble, and thus acts as an inhibitor of bone remodeling and resorption. Unlike RANK and RANKL, OPG does not have a transmembrane domain or cytoplasmic domain [28]. OPG is thus a decoy receptor, which interferes with the osteoclastic RANKL/RANK signaling to prevent bone loss [29].

The four cysteine rich pseudo repeats form an elongated structure and binds to one of the grooves of the active RANKL therefore preventing RANKL/ RANK interaction and hence osteoclastogenesis. OPG production is modulated by several cytokines, vitamins, estrogens and other molecules, thereby modulating osteoclastogenesis and bone resorption. OPG production is induced by $1 \alpha, 25$-dihydroxyvitamin $\mathrm{D}_{3}$, estrogens, proinflammatory cytokines such as interleukin-1 (IL-1) and TNF- $\alpha$ as well as transforming growth factor- $\beta$ (TGF- $\beta$ ), whereas parathyroid hormone (PTH) and glucocorticoids inhibit OPG production. OPG expression is modulated by biphosphonates in osteoblasts $[30,31]$.

Another study has also highlighted the possibility of bone derived OPG to increase survival of breast cancer cells that reach the bone microenvironment as part of the metastatic process thus promoting the breast cancer mediated bone osteolysis [32]. Aggressive breast cancer malignancies metastasize to bone and are associated with dysregulation of the RANK/RANKL/OPG pathway and can increase the RANKL/OPG ratio, which would favor excessive osteolysis [33]. OPG blocks the maturation of bone resorbing osteoclast cells in the bone microenvironment thus preventing bone resorption. OPG does not have a transmembrane domain or cytoplasmic domain [11]. A high affinity anti-RANKL monoclonal antibody denosumab (AMG162; bone antiresorptive drug) targeting the osteoblast/cancer cell interphase has been developed to prevent bone loss in prostate and breast cancer bone metastases by slowing down bone turnover, hence prostate and breast cancer growth on the skeleton [29]. Clinical phase III study showed that even patients with breast cancer without bone metastases but with reduced bone density due to treatment with aromatase inhibitors benefit from treatment with denosumab [34]. The treatment significantly increased bone density after 1-2 years compared with the placebo treated control group
[34]. AMGN-0007 is a recombinant OPG construct and suppressed bone resorption when administered to multiple myeloma (MM) and breast cancer patients during a phase I clinical trial [35].

Knocking down OPG expression in triplenegative breast cancer cells led to a significant reduction in metastasis in the chick embryo metastasis model. A reduction in metastasis was observed from both a primary tumor and by intravenous injection of tumor cells, suggesting a direct impact of OPG on metastasis [2]. The discovery that OPG is a potent inhibitor of osteoclast activity and maturation initiated research into the possibility of using this molecule as a therapeutic agent for the treatment of a variety of conditions associated with increased bone resorption, including tumor-induced bone disease [36].

\section{OPG AS A SURVIVAL FACTOR}

Discovery of OPG's ability to bind and inhibit the activity of TRAIL (TNF related apoptosis inducing ligand) opened an altogether new avenue for research suggesting that OPG production may provide cells with a survival advantage (Figure 2) [37]. TRAIL is produced in tumors by invading monocytes, inducing apoptosis in neoplastic cells sensitive to this cytokine. It has been shown in MDA-MB 436 and MDA-MB 231 cells that OPG produced by breast cancer cells enhances tumor cell survival by inhibiting TRAIL-induced apoptosis [18]. In vitro studies using a number of different tumor types have supported this hypothesis [18, 32, 38-40] but an undisputed functional link between OPG and cell survival in cancer has been not established to date. Resistance to apoptosis being a hallmark of cancer also correlates with aggressiveness of the tumor and poor prognosis. Wnt/ßcatenin, a major pathway of cell proliferation and growth has been shown to drive OPG expression thus leading to cell survival in colon cancer (Figure 2) [41]. In addition, the OPG produced by endothelial cells may increase survival through binding to TRAIL, thus helping the tumor cells to proliferate and increase metastatic bulk (Figure 2). One of the study highlighted the association of OPG expression in endothelial cells with increased tumor grade. The study also reported negative correlation between endothelial OPG and ER status of the tumors. OPG has been shown to be able to act as an autocrine survival factor for both breast and prostate tumor cells in vitro and this could also be a mechanism used by endothelial cells potentially favored by conditions within high grade tumors [42].

Apart from inducing angiogenesis and bypassing apoptosis by quenching TRAIL ligand, our study [6] for the first time demonstrated that OPG has the potential of reprogramming healthy human mammary epithelial spheres (HMEC), driving them towards tumorigenesis 
Table 1: Comparison of copy number variations in breast cancer cell lines, inflammatory breast cancer tissue from patient, and HMEC sphere cultures grown for long time in the presence of OPG rich microenvironment.

\begin{tabular}{|c|c|c|c|c|}
\hline Gene & SUM149PT & SUM1315MO2 & $\begin{array}{l}\text { Patient } \\
\text { sample }\end{array}$ & $\begin{array}{c}\text { HMEC sp w/ } \\
500 \mathrm{pg} / \mathrm{ml} \\
\text { rhOPG }\end{array}$ \\
\hline $\begin{array}{c}\text { AKT1 } \\
\text { (serine-threonine } \\
\text { kinase) }\end{array}$ & $\checkmark$ & $\checkmark$ & $\checkmark$ & $\checkmark$ \\
\hline $\begin{array}{c}\text { AURKA } \\
\text { (Aurora-A kinase) }\end{array}$ & $\checkmark$ & $\checkmark$ & $\checkmark$ & $\checkmark$ \\
\hline $\begin{array}{c}\text { CDK4 } \\
\text { (cell cycle } \\
\text { progression) }\end{array}$ & $\checkmark$ & $\checkmark$ & $\checkmark$ & $\checkmark$ \\
\hline $\begin{array}{c}\text { EGFR } \\
\text { (surface receptor) }\end{array}$ & $\checkmark$ & $\checkmark$ & $\checkmark$ & $\checkmark$ \\
\hline $\begin{array}{c}\text { ERBB2 } \\
\text { (RTK; oncogene) }\end{array}$ & $\checkmark$ & $\checkmark$ & $\checkmark$ & $v$ \\
\hline $\begin{array}{c}\text { MYC } \\
\text { (regulator of } \\
\text { transcripton) }\end{array}$ & $\checkmark$ & $\checkmark$ & $\checkmark$ & $\checkmark$ \\
\hline $\begin{array}{c}\text { PAK } 1 \\
\text { (RhoGTPases) }\end{array}$ & $\checkmark$ & $\checkmark$ & $\checkmark$ & $\checkmark$ \\
\hline $\begin{array}{c}\text { PTEN } \\
\text { (tumor sup.) }\end{array}$ & $x$ & $x$ & $x$ & $x$ \\
\hline $\begin{array}{c}\text { CDKN2A } \\
\text { (CDK inhibitor) }\end{array}$ & $x$ & $x$ & $x$ & $x$ \\
\hline $\begin{array}{c}\text { RB1 } \\
\text { (tumor sup.) }\end{array}$ & $x$ & $x$ & $\mathbf{x}$ & $\mathbf{x}$ \\
\hline TOP2A & $x$ & $x$ & $x$ & $x$ \\
\hline
\end{tabular}

Red check marks denote the remarkably high gene expression of AKT1, AURKA, CDK4, EGFR1, ERBB2, PAK1 and MYC copy number in the DNA prepared from sphere cultures of SUM149PT, SUM1315MO2, inflammatory breast cancer tissue from patients, and HMEC spheres cultured for long time in the presence of human recombinant OPG (500pg/ml). Green crosses depict the downregulation of tumor suppressors (RB1 and PTEN), cycle regulator CDKN2A, and DNA repair enzyme topoisomerase DNA II alpha TOP2A in SUM149PT, SUM1315MO2, inflammatory breast cancer tissue from patients, and HMEC spheres cultured for long time in the presence of human recombinant OPG (500pg/ml).

thus mimicking the scenario in breast cancer spheres (Figure 2). The addition of OPG to the normal HMEC growth media induced proliferation in the HMEC spheres. Another study [43] showed that intra-tibial tumors from the MCF-7 cells overexpressing OPG had an increase in cells staining positive for the proliferation marker Ki67. These observations together suggest that OPG can induce proliferation. Apart from a drastic increase in proliferation, few morphological changes were also induced in the control spheres. Aneuploidy, a hallmark of cancer, has been proposed to initiate tumorigenesis and is a remarkably common characteristic of tumor cells [44]. The increase in proliferation in HMEC spheres can be corroborated with the onset of aneuploidy markers such as IAK-1, Bub-1 and BubR1 [6].

Our goal was to decipher the cellular mechanisms of how OPG modulates and reprograms the normal mammary epithelial cells to a tumorigenic state thus suggesting promising avenues for treating IBC as well as highly invasive breast cancer with new therapeutic targets [6]. Our study also highlighted how OPG upregulates the phophorylated survival kinases such as Erk, Akt, GSK3 $\beta$ and p65 in HMEC spheres which contends the increased proliferation as seen in HMEC spheres in the presence of OPG (Figure 2) [6]. With DNA copy number variations $(\mathrm{CNVs})$ in cancer cells having prognostic impact, it opens several avenues for therapeutic treatment and translational research. OPG selectively amplified the DNA copy numbers of AKT1, AURK1, EGFR, MYC and PAK1, CDK4 and downregulated tumor suppressive CDKN2A, PTEN and TOP2A genes (Table 1) [6]. OPG has been reported to exert its effects via OPG receptors, such as type II membrane forms of RANKL [45, 46], TRAIL [47] and heparan sulfate containing proteoglycans, such 
as syndecan-1 (Figure 2) [13, 48]. Interestingly, our study for the first time showed how one of the crucial breast cancer stem cell markers CD24 was upregulated in HMEC spheres in the presence of OPG which also supports the sustained proliferation in control spheres.

Recent studies have demonstrated OPG expression in breast cancer tissue samples and in a large cohort of invasive breast cancers $(n=400), 40 \%$ of samples showed OPG expression that was confined to tumor cells [18]. Interestingly, the gain in OPG gene copies was observed in 182 out of 934 tumors when the TCGA-2013 human breast invasive carcinoma data set was analyzed through the cBioPortal website [2]. The presence of an OPG copy number gain is a significant predictor of decreased overall survival or poorer prognosis in this cohort [2].

\section{OPG AND ANGIOGENESIS}

Angiogenesis is an essential step for breast cancer progression and dissemination. The development of new blood vessels in a tumor setting (angiogenesis) is conducted by numerous physiological and pathological stimuli. These stimuli can be various cytokines, chemokines, and growth factors. Molecular players of angiogenesis have been characterized since the early years of angiogenic studies, and one of the most prominent stimulating growing factors is certainly the vascular endothelial growth factor (VEGF) family. The most prominent member of this family, VEGF, is the foremost controller of physiological and pathological angiogenesis. An increasing number of reports now consider that OPG

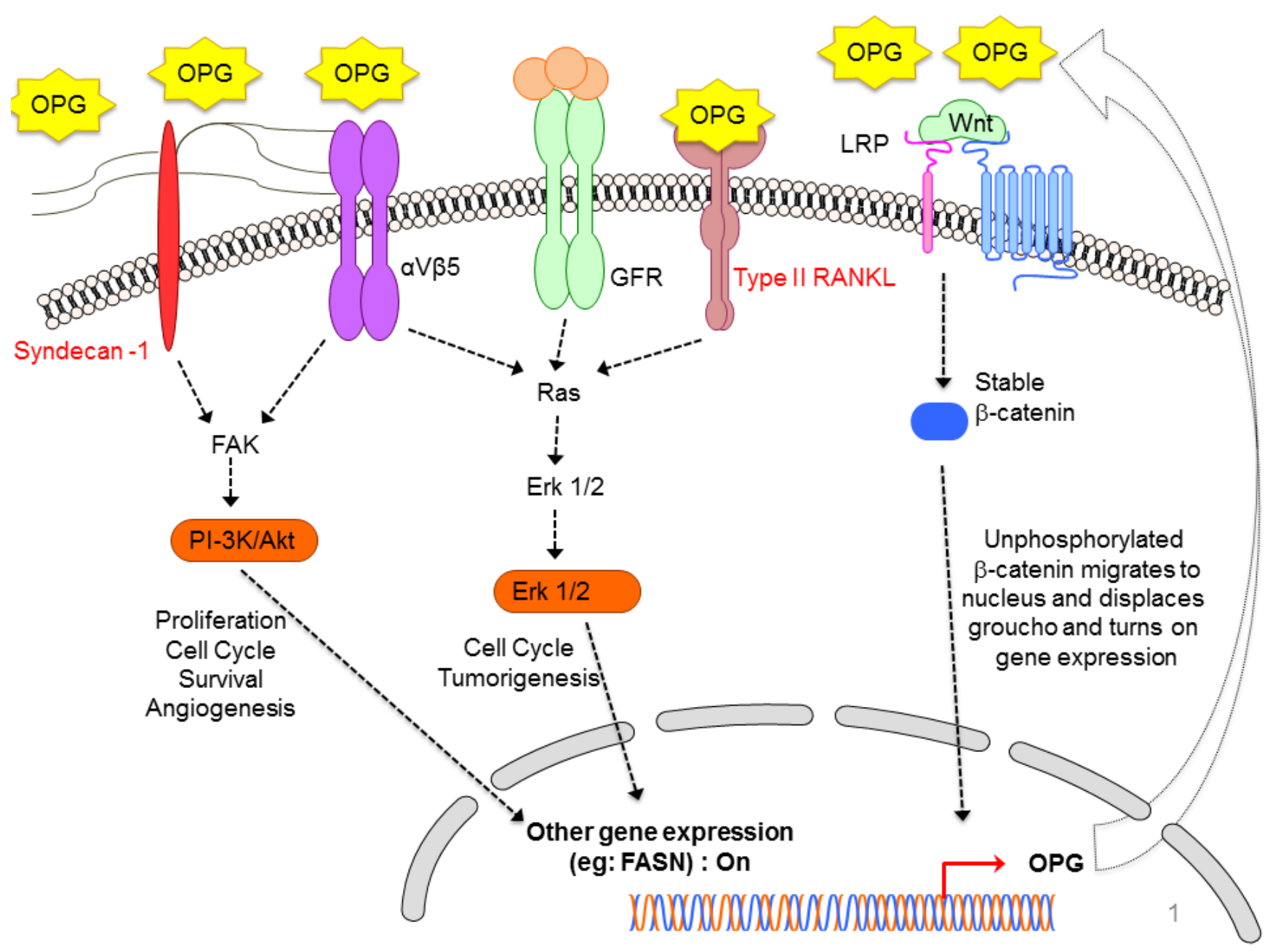

Figure 2: Schematic diagram depicting the diverse signaling pathways that are triggered or modulated by OPG. OPG can bind to various cell surface receptors such as Syndecan-1, membranous RANKL, and $\alpha$ V $\beta 5$ integrin in order to trigger different cell survival pathways particularly, ERK, PI-3K/Akt pathway which results in expression of various cell survival favorable genes. Simultaneously, stable $\beta$-catenin of the canonical Wnt/ $\beta$-catenin pathway, which is turned on in the majority of cancer cells, translocate to nucleus and turns on OPG gene expression. The OPG gets secreted out of the cell in the microenvironment, and can exert its paracrine and autocrine effects. The released OPG can affect the nearby healthy cells thus driving them towards tumorigenesis. The released OPG can also exert autocrine effects on the cancer cells by binding to cell surface receptors. The binding of OPG turns on the vicious cell survival signaling in cancer cells thus favoring their growth, proliferation, survival, angiogenesis [6]. 
also has a function in other biological systems, including the vasculature [49-51]. It is highly possible that OPG produced either by the endothelial cells themselves or by the surrounding tumor cells, may result in increased endothelial cell survival and differentiation to form blood vessels, thereby facilitating tumor growth. OPG has been implicated in microvascular endothelial cell proliferation, migration, and induction of angiogenesis (Figure 2) [52].

Involvement of the heparin-binding domain D7 in OPG's proangiogenic activity has been suggested by McGonigle et al. 2009 [53]. OPG may interact with endothelial colony forming cells (ECFCs) through its binding to HSPG's, syndecan-1 (Figure 2), thereby exerting an anti-adhesive effect and promoting ECFC migration through a SDF-1/CXCR4 dependent pathway (as well as the MAPK and the Akt cascades), finally facilitating their recruitment to sites of neoangiogenesis $[54,55]$. Our study [6] also corroborates the previous findings $[42,54,56]$ highlighting OPG's important role in angiogenesis and neovasculogenesis in endothelial tube formation in an in vitro model of angiogenesis (Figure 2). When we used $500 \mathrm{pg} / \mathrm{ml}$ and $1100 \mathrm{pg} / \mathrm{ml} \mathrm{rhOPG}$, the length of the neovascular tubes were increased along with the number of branch points when compared to control media without rhOPG [6]. Quantitatively, conditioned media from SUM149PT and SUM1315MO2 adherent cell conditioned medium induced $\sim 5$-fold and 2.5 fold more branch points/field, respectively than HMEC medium [6]. However, OPG-depleted SUM149PT and SUM1315MO2 conditioned media reduced node formation by 36 and $51 \%$, respectively [6].

\section{OPG AND ITS BINDING PARTNERS IN BREAST CANCER CELLS}

In our quest to understand more about the binding partners of OPG we performed mass spectrometry analysis. OPG pulled down proteins controlling cell proliferation (nucleolin, IQGAP1/3, proliferation inducing gene 32, proliferation inducing gene 44), proteins involved in transport and fusion (valosin and ATP binding cassette), and proteins involved in gene expression (Leucine rich PPR, DHX9 or DEAH, t-RNA synthetase) (Figure 3) (unpublished results). OPG pulled down many cytoskeleton elements such as myosin, filamin, keratin, ankyrin, vinculin, and $\alpha$-actinin (Figure 3) (unpublished results).

Interestingly, immunoprecipitation of breast cancer cell extracts by OPG antibody revealed a major band at a molecular mass of $110 \mathrm{kDa}$ (unpublished results). Mass spectrometry analysis revealed it to be the protein nucleolin (Figure 3) (unpublished results). Nucleolin is a multifunctional shuttling protein present in the nucleus, cytoplasm, and on the surface of some types of cells. Nucleolin is a major constituent of nucleoli in exponentially growing cells and functions in the organization of nucleolar chromatin, packaging of prerRNA, rDNA transcription, and ribosome assembly by shuttling between the nucleus and the cytoplasm [5759]. Expression of nucleolin on the cell surface has been reported in HeLa cells [60], lymphoblastoid T cells [60], breast carcinoma cells [61, 62], lung [63], and laryngeal epithelial cells [64], and hepatocarcinoma cells [68]. Nucleolin is expressed on the surface of endothelial cells in angiogenic blood vessels [65]. The interaction between nucleolin and OPG in breast cancer cells adds another layer of complexity to how OPG could be manipulating functions at the nuclear levels, and these studies are ongoing in our lab.

The observation of cytoskeleton elements being pulled down validates with findings that have been reported previously [43]. Studies have investigated the mechanism whereby OPG could promote angiogenic behavior of endothelial cells. Human dermal microvascular endothelial cells (HuDMECs) treated with OPG were elongated with extensive actin networks compared to untreated cells [43]. This was due to cytoskeletal reorganization and cell spreading which was mediated by Focal Adhesion Kinase (FAK) as phosphorylation of FAK at tyrosine 397 was induced by treatment with OPG [43].

Valosin-containing proteins; also known as p97 or VCP, is an abundant ATPase which has the ability to use the energy derived from ATP hydrolysis to unfold client proteins [65]. VCP engages in a range of cellular processes such as ER-associated degradation (ERAD) that mediates the extraction of misfolded proteins across the ER membrane and their delivery to the proteasome. The ATPase valosin-containing protein (VCP; p97) is an essential regulator of protein degradation in multiple pathways and has emerged as a target for cancer therapy. VCP inhibition affects protein synthesis, eukaryotic initiation factor $2 \alpha$ (eIF $2 \alpha$ ) and mechanistic target of rapamycin complex 1 (mTORC1), and attenuates global protein synthesis. VCP inhibitors perturb intracellular amino acid levels, activated eukaryotic translation initiation factor $2 \alpha$ kinase 4 (EIF2AK4), and enhance cellular dependence on amino acid supplies, consistent with a failure of amino acid homeostasis [65]. Thus, depletion of VCP triggers cancer cell death in part through inadequate control of protein synthesis and amino acid metabolism, and allows it to have implications for the development of anti-cancer therapies [65, 66]. OPG's interaction with $\mathrm{VCP}$ in the context of invasive and inflammatory breast cancer opens up many interesting avenues to research the therapeutic implications.

OPG interestingly pulled down lipid metabolic enzyme, fatty acid synthase (FASN), which is a key enzyme of the fatty acid biosynthetic pathway in breast cancer cells (Figure 3) (unpublished results). FASN controls the process of producing de novo fatty acids from carbohydrate and amino acid-derived carbon sources [67]. FASN is a multifunctional polypeptide enzyme 
that produces saturated fatty acids, uses one acetyl-CoA and sequentially adds seven malonyl-CoA molecules to produce the 16-carbon saturated palmitic acid [67]. Overexpression of FASN has been strongly associated with many cancer types because it plays important metabolic roles in molecular pathways regulating cancer cell proliferation and tumor development [67]. Reduction in FASN enzyme activity by chemical inhibitors including orlistat, cerulenin and triclosan have been reported to remarkably decrease progression in various cancer cell types [68]. FASN is an attractive therapeutic target as it regulates neoplastic transformation, metastasis as well as angiogenic pathways manipulating tumor vascularity and cell proliferation [69]. It also serves as a potential diagnostic and prognostic biomarker as it is secreted in the blood of patients with breast, prostate, colon and ovarian cancers compared with normal healthy subjects [69]. In our recent study we demonstrated that compared to HMEC, SUM149PT and SUM1315MO2 breast cancer cells express increased level of FASN [70]. We have several interesting findings in the context of paracrine signaling in the OPG rich breast cancer microenvironment that drives carcinogenesis via inducing and sustaining inflammatory cycloxygenase-2 (COX-2) and lipogenic FASN in an invasive breast cancer setting (Figure 3) (unpublished results). Our lab findings reveal the synergistic anti-proliferative role of the COX-2 inhibitor celecoxib and FASN blocker C75 in aggressive metastatic breast cancer cells (Figure 3) (unpublished results).

\section{OPG IN CANCERS AND OTHER DISEASES}

OPG has been reported to have connection with Prostate cancer, which is one of the malignancies that have great avidity to bone as advanced prostate cancer commonly metastasizes to bone leading to osteoblastic and osteolytic lesions [71]. Prostate cancer cells secrete OPG and in vitro OPG can protect the tumor cells from apoptosis via its ability to inhibit TRAIL and the apoptotic mechanisms it activates [18, 38, 40]. In contrast, in vivo OPG was shown to inhibit the survival of prostate cancer cells in bone $[72,73]$. A potential role for serum OPG as a marker of early relapse in prostate cancer is suggested by the study of Eaton et al. 2004 [74]. Here, they compared serum OPG levels in 104 prostate cancer patients, ten cases of benign prostatic hyperplasia, and ten healthy young men [74]. The prostate cancer patients were divided into several groups: untreated patients with (i) organ confined or (ii) locally advanced disease, (iii) patients with advanced disease responding to androgen ablation and (iv) patients with early signs of disease progression. Serum OPG was found to increase in patients who progressed following androgen ablation, and this increase was detectable prior to elevation of the classical marker prostate specific antigen (PSA). The authors [74] suggest that serum OPG may not simply be a marker of advanced

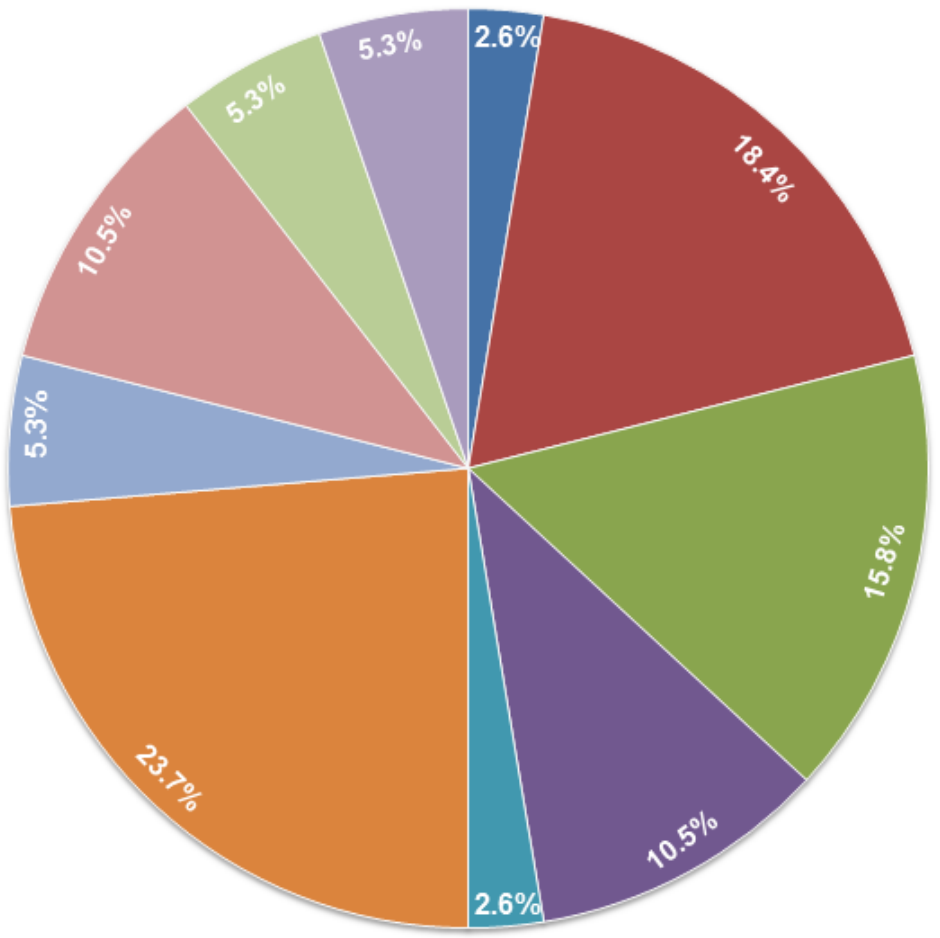

- Proteolytic activity

- Chaperone \& protein folding

- Growth/ proliferation/differentiation

- Transcription/translation regulation

- Structural

Cytoskeletal elements

Metabolism

- Signal transducing activity

DNA/Base pair repair machinery

Angiogenesis

Figure 3: Pie chart depicting the binding partners of OPG from mass spectrometry analysis. A. pull-down with anti-OPG antibody revealed a myriad of proteins involved in different cellular functions in inflammatory and aggressive breast cancer cells. 
disease, but indicate changes in tumor cell survival and growth. The proinflammatory cytokine TNF- $\alpha$ has been demonstrated to drive OPG production in a variety of cell types and prostate cancers [75].

One of the major clinical features of multiple myeloma is the development of osteolytic bone disease and, over recent years, there is increasing evidence to suggest that the dysregulation of the RANK/RANKL/OPG system is important in the pathogenesis of myeloma bone disease. One study [76] has shown a subset of melanomas constitutively produce soluble OPG. OPG expression is regulated by the presence or absence of TNFR1 on melanomas, and melanomas drive OPG production in the absence of accessory cells through autocrine signaling via surface expression of mTNF. OPG levels are dramatically elevated in some colon carcinoma cells and that its secretion is potently upregulated by inflammatory cytokines such as TNF- $\alpha$ and IL-1 [77]. Increased serum OPG levels have been reported in patients with colorectal cancer (CRC) [41]. Interestingly, overexpression of OPG at the invasive tumor front plays a critical role in the initiation of progression and metastasis of CRC and high OPG level is a novel marker for recurrence after curative surgery for CRC [78]. The study also suggests OPG's potential to be used as a reliable biomarker to decide whether to use adjuvant chemotherapy in patients with CRC after surgery [78].

Ito et al. [79] examined the expression of OPG by gastric carcinoma cell lines and material from 103 cases of primary gastric carcinomas by gene expression analysis and immunohistochemistry, and related OPG expression to clinicopathological information such as tumor stage, depth of invasion, presence of lymph node metastasis and prognosis. They report a significant correlation between OPG expression and depth of tumor invasion, nodal metastasis and tumor stage, with strong OPG expression more frequent in stages III and IV than stages I and II. Mizutani et al. 2004 [80] demonstrated that serum OPG concentration is correlated with both tumor stage and tumor grade and that elevated serum OPG levels are predictive of early recurrence in patients with bladder carcinoma. These findings suggest that serum OPG concentration may have utility as a prognostic parameter in this setting.

OPG overexpression has also been related to poor prognosis for pancreatic cancer $(\mathrm{PaC})$ and is a key modulator of metastasis and resistance to TRAILinduced apoptosis [81]. Shi et al. 2014 showed increased OPG expression in $\mathrm{PaC}$ tissues compared with normal pancreas, and in $\mathrm{PaC}$ tumors [81]. OPG overexpression was associated with new-onset $\mathrm{PaC}$-diabetes mellitus (PaC-DM) [81]. Patients with new-onset PaC-DM had a higher serum OPG level than those without diabetes mellitus [81]. These findings suggest that in at least a portion of $\mathrm{PaC}$ tissues, islet cells would face high OPG stress, and thus be more susceptible to damage than normal human islets. Taken together these studies also provide the rationale to consider OPG as a diabetogenic factor and most importantly as a candidate target for new approaches to retard the development of PaC-DM [81]. Toffoli et al. 2011 [82] found that OPG induces morphological alterations and reduction of islet function in mouse pancreatic islets. Serum OPG level may be used as a diagnostic tool and a prognostic variable for patients with muscle invasive bladder cancer. Future trials are required to elucidate its therapeutic role in such patients [83].

OPG is also involved in many other diseases unrelated to cancer. OPG was recently defined as an important cardiovascular (CV) marker in the general population with arterial stiffness, vascular calcification, and carotid intima media thickness [84]. OPG constitutes a novel biomarker with prognostic significance in patients with severe malaria. In addition, further studies are required to determine whether OPG plays a role in modulating malaria pathogenesis [85]. Circulating OPG levels are increased in patients with acute coronary syndrome [86] and enhanced expression has been found within symptomatic carotid plaques [87]. Elevated OPG levels have also been associated with the degree of coronary calcification in the general population as a marker of coronary atherosclerosis [88]. OPG levels were higher in obese than in normal subjects and HDL-C was also associated with OPG levels in obese women [89]. OPG has been reported to predict survival in patients with heart failure after acute myocardial infarction [90] to predict heart failure hospitalization and mortality in patients with acute coronary syndrome [86] and to be associated with long-term mortality in patients with ischemic stroke [91].

\section{OPG AND GENETIC POLYMORPHISM}

The occurrence of single nucleotide polymorphisms (SNPs) in the OPG gene in association with breast cancer has been examined. Ney et al. 2013 [92] for the first time reported a significant association between the SNP rs3102735 (5' near promoter region containing the minor allele $\mathrm{C}$ as well as for the homo- and heterozygous genotype with the minor allele $\mathrm{C}$ ) of the OPG gene and the susceptibility of breast cancer in Caucasian populations. A 1.5-fold increased risk of breast cancer was associated with SNP rs3102735 [92]. Another study reported that the $\mathrm{C}$ allele of the OPG SNP rs2073618 and the T allele of the OPG SNP rs2073617 occurred more frequently in breast cancer patients [93]. The variant $\mathrm{C}$ allele of 950 $\mathrm{T} / \mathrm{C}$ in the OPG promoter has been reported to play a major role as a genetic safe guard against progression in patients with prostate cancer [94]. The analysis of OPG gene variants C950T (promoter) and C1181G (exon 1) revealed that the presence of polymorphic $1181 \mathrm{G} / 950 \mathrm{~T}$ alleles and $950 \mathrm{TT} / 1181 \mathrm{GG}$ genotypes may play a role in 
the development of bone disease [95]. Apart from breast cancer, genetic variations in form of polymorphisms in OPG and RANKL have also been associated with bone fractures in premenopausal patients with systemic lupus erythematosis (SLE) [96]. OPG/A163G polymorphism has been suggested to contribute to the genetic regulation of bone mineral density or bone turnover markers in Slovak population and thus could increase or decrease osteoporosis risk [97]. 163A/G (rs3102735) and 950T/C (rs2073617) polymorphisms of OPG have been evaluated in patients with pre-eclampsia (60 cases of early-onset severe pre-eclampsia and 91 cases of late-onset preeclampsia) [98].

Kwan et al., 2014 used a meta-analysis of GWAS from FIVE studies comprising $>10000$ individuals from European and Asian origin, and identified two genomewide significant loci (8q23-q24.1 and 17q11.2) and one locus on chromosome 14 associated with OPG levels with near genome-wide significance [99]. In conclusion, they discovered that variants $>100 \mathrm{~kb}$ upstream of the gene encoding OPG are associated with variation in circulating OPG levels and identified another new significant locus on chromosome 17q11.2 as well as a suggestive locus on chromosome 14q21.2 associated with the trait [99]. They estimated that over half of the heritability of age-adjusted OPG levels could be explained by all SNPs studied [99].

\section{PERSPECTIVES}

Despite the wealth of literature on OPG, there are many questions still unresolved, including the exact role of OPG in bone metastasis of breast cancer and the therapeutic potential of targeting OPG. Besides roles in cancer, OPG plays role(s) in bone metabolism, endometriosis, periodontal disease, thyroid disease and coronary heart disease [11]. Though OPG can modulate breast tumor growth and progression, future studies required to fully determine the mechanism of effect and overall outcomes of the different types of interactions required to determine whether strategies to block OPG signaling would be effective in blocking the development of primary breast tumors [43]. At this point OPG can no longer be considered solely in the bone microenvironment in breast cancer and caution must be exercised in the development of systemic treatment strategies aimed at increasing OPG levels. Localized delivery of OPG to the bone may be more appropriate to inhibit osteolysis linked metastatic breast cancer [43].

Conditionally replicating adenoviruses (CRAds) have been used as anticancer agents designed to infect and lyse tumor cells. In a murine model of osteolytic bone metastases of breast cancer, the CRAd armed with shortened OPG (sOPG)-Fc reduced tumor burden in the bone and inhibited osteoclast formation more effectively than an unarmed CRAd suggesting the role of OPG [17]. Breast cancer development in BRCA1/2 mutation carriers is a consequence of autonomous and nonautonomous cell factors, which serve as excellent targets for cancer prevention. BRCA-mutation carriers were reported to have lower mean values of free serum OPG in particular in BRCA1-mutation carriers compared with controls [100]. OPG may become a new biomarker and a target of treatment for patients with colorectal cancer since many studies have revealed the clinicopathologic significance of OPG expression by using clinical tissue samples from patients [78]. The effects of sustained expression of OPG using a recombinant adeno-associated viral (rAAV) vector in a mouse model of osteolytic breast cancer has clearly indicated the potential of $\mathrm{AAAV}-\mathrm{OPG}$ therapy for reducing morbidity and mortality in breast cancer patients with osteolytic bone damage [101]. With all this development in the understanding of OPG, there might be more therapeutic avenues to manipulate OPG to predict and manage aggressive forms of breast cancer.

\section{Abbreviations}

TME: tumor microenvironment; ECM: extracellular matrix; OPG: osteoprotegerin; TNFR: tumor necrosis factor receptor; TRAIL: TNF related apoptosis inducing ligand; IBC: Inflammatory breast cancer; RANKL: receptor activator of nuclear factor (NFKB) ligand; OCIF: osteoclastogenesis inhibitory factor; FDCR-1: follicular DC-derived receptor-1; MSCs: mesenchymal stem cells; TAFs: tumor associated fibroblasts; PDGF: platelet derived growth factor; IL-1: interleukin-1; IL-6: interleukin-6; IL-8: interleukin-8; CCL-5: Chemokine (C-C motif) ligand 5; TNF- $\alpha$ : tumor necrosis factor- $\alpha$; TGF- $\beta$ : transforming growth factor- $\beta$; PTH: parathyroid hormone; PSA: prostate specific antigen; HSPGs: heparin sulfate proteoglycans; HuDMECs: Human dermal microvascular endothelial cells; FAK: Focal Adhesion Kinase; VEGF: vascular endothelial growth factor; $\mathrm{PaC}$ : pancreatic cancer; Pa-DM: PaC-diabetes mellitus; FASN: Fatty acid synthase; IQGAP1/3: IQ Motif Containing GTPase Activating Protein 1/3; CRAds: Conditionally replicating adenoviruses; CRC: colorectal cancer; ECFC: endothelial colony forming cells; AURK1/IAK1: Aurora A Kinase; EGFR: epidermal growth factor receptor; MYC and PAK1, CDK4: Cyclin-Dependent Kinase 4; CDKN2A: Cyclin-Dependent Kinase Inhibitor 2A; PTEN: Phosphatase and tensin homolog; TOP2A: topoisomerase (DNA) II Alpha.

\section{ACKNOWLEDGMENTS}

This study was supported by Rosalind Franklin University of Medicine and Science start-up funds and RFUMS-Advocate Lutheran General Hospital grant to NSW. We thank Keith Philibert for critically reading the manuscript. 


\section{CONFLICTS OF INTEREST}

No potential conflicts of interest exist.

\section{REFERENCES}

1. Paolo V, De Lorenzi Francesca, Pietro L, Mario R, Umberto V. Current Trends in the Oncologic and Surgical Managements of Breast Cancer in Women with Implants: Incidence, Diagnosis, and Treatment. Aesthetic Plast Surg. 2016; 40(2):256-65.

2. Weichhaus M, Segaran P, Renaud A, Geerts D, Connelly L. Osteoprotegerin expression in triple-negative breast cancer cells promotes metastasis. Cancer Med. 2014; 3(5): 111225.

3. Al-Faham Z, Al-Katib S, Jaiyesimi I, Bhavnagri S. Evaluation of a Case of Inflammatory Breast Cancer with 18 F-FDG PET/CT. Journal of nuclear medicine technology. 2015; 43(4): 289-91.

4. Jaiyesimi IA, Buzdar AU, Hortobagyi G. Inflammatory breast cancer: a review. Journal of clinical oncology.1992; 10(6): 1014-24.

5. Bissell MJ, Hines WC. Why don't we get more cancer? A proposed role of the microenvironment in restraining cancer progression. Nature medicine. 2011; 17(3): 320-9.

6. Goswami S, Sharma-Walia N. Osteoprotegerin secreted by inflammatory and invasive breast cancer cells induces aneuploidy, cell proliferation and angiogenesis. BMC cancer. 2015; 15: 935.

7. Simonet WS1, Lacey DL, Dunstan CR, Kelley M, Chang MS, Lüthy R, Nguyen HQ, Wooden S, Bennett L, Boone T,Shimamoto G, DeRose M, Elliott R et, al. Osteoprotegerin: a novel secreted protein involved in the regulation of bone density. Cell. 1997; 89(2): 309-19.

8. Tsuda E, Goto M, Mochizuki S, Yano K, Kobayashi F, Morinaga T, Higashio K. Isolation of a novel cytokine from human fibroblasts that specifically inhibits osteoclastogenesis. Biochem Biophys Res Commun. 1997; 234 (1): 137-42.

9. Kwon BS, Wang S, Udagawa N, Haridas V, Lee ZH, Kim KK, Oh KO, Greene J, Li Y, Su J, Gentz R, Aggarwal BB, Ni J. TR1, a new member of the tumor necrosis factor receptor superfamily, induces fibroblast proliferation and inhibits osteoclastogenesis and bone resorption. FASEB J. 1998; 12(10): 845-54.

10. Yun TJ, Chaudhary PM, Shu GL, Frazer JK, Ewings MK, Schwartz SM, Pascual V, Hood LE, Clark EA. OPG/FDCR1 , a TNF receptor family member, is expressed in lymphoid cells and is up-regulated by ligating CD40. J Immunol. 1998; 161(11): 6113-21.

11. Holen I, Shipman CM. Role of osteoprotegerin (OPG) in cancer. Clin Sci (Lond). 2006; 110(3): 279-91.

12. Nelson CA, Warren JT, Wang MW, Teitelbaum SL, Fremont DH. RANKL employs distinct binding modes to engage RANK and the osteoprotegerin decoy receptor. Structure. 2012; 20(11): 1971-82.

13. Mosheimer BA, Kaneider NC, Feistritzer C, Djanani AM, Sturn DH, Patsch JR, Wiedermann CJ. Syndecan-1 is involved in osteoprotegerin-induced chemotaxis in human peripheral blood monocytes. The Journal of clinical endocrinology and metabolism. 2005; 90(5): 2964-71.

14. Zauli G, Melloni E, Capitani S, Secchiero P. Role of fulllength osteoprotegerin in tumor cell biology. Cell Mol Life Sci. 2009; 66(5): 841-51.

15. Tan KB, Harrop J, Reddy M, Young P, Terrett J, Emery J, Moore G, Truneh A.. Characterization of a novel TNF-like ligand and recently described TNF ligand and TNF receptor superfamily genes and their constitutive and inducible expression in hematopoietic and non-hematopoietic cells. Gene. 1997; 204(1-2): 35-46.

16. Thomas RJ, Guise TA, Yin JJ, Elliott J, Horwood NJ, Martin TJ, Gillespie MT. Breast cancer cells interact with osteoblasts to support osteoclast formation. Endocrinology. 1999; 140(10): 4451-8.

17. Cody JJ, Rivera AA, Lyons GR, Yang SW, Wang M, Sarver DB, Wang D, Selander KS, Kuo HC, Meleth S, Feng X, Siegal GP, Douglas JT. Arming a replicating adenovirus with osteoprotegerin reduces the tumor burden in a murine model of osteolytic bone metastases of breast cancer. Cancer Gene Ther. 2010; 17(12): 893-905.

18. Holen I, Cross SS, Neville-Webbe HL, Cross NA, Balasubramanian SP, Croucher PI, Evans CA, Lippitt JM, Coleman RE,Eaton CL. Osteoprotegerin (OPG) expression by breast cancer cells in vitro and breast tumours in vivo--a role in tumour cell survival? Breast Cancer Res Treat. 2005; 92(3): 207-15.

19. Beacham DA, Cukierman E. Stromagenesis: the changing face of fibroblastic microenvironments during tumor progression. Semin Cancer Biol. 2005; 15(5): 329-41.

20. Wels J, Kaplan RN, Rafii S, Lyden D. Migratory neighbors and distant invaders: tumor-associated niche cells. Genes Dev 2008; 22(5): 559-74.

21. Reddy BY, Lim PK, Silverio K, Patel SA, Won BW, Rameshwar P. The Microenvironmental Effect in the Progression, Metastasis, and Dormancy of Breast Cancer: A Model System within Bone Marrow. Int J Breast Cancer. 2012; 2012: 721659.

22. Rhodes LV, Antoon JW, Muir SE, Elliott S, Beckman BS, Burow ME. Effects of human mesenchymal stem cells on ER-positive human breast carcinoma cells mediated through ER-SDF-1/CXCR4 crosstalk. Mol Cancer. 2010; 9: 295.

23. Senst C, Nazari-Shafti T, Kruger S, Höner Zu Bentrup K, Dupin CL, Chaffin AE, Srivastav SK, Wörner PM, AbdelMageed AB, Alt EU, Izadpanah R.. Prospective dual role of mesenchymal stem cells in breast tumor microenvironment. Breast Cancer Res Treat. 2013; 137(1): 69-79.

24. Labovsky V, Martinez LM, Davies KM, García-Rivello H, Calcagno Mde L, Matas A, Fernández Vallone VB, 
Wernicke A, Choi H, Chasseing NA. Association between ligands and receptors related to the progression of early breast cancer in tumor epithelial and stromal cells. Clin Breast Cancer. 2015; 15(1): e13-21.

25. Ney JT, Fehm T, Juhasz-Boess I, Solomayer EF. RANK, RANKL and OPG Expression in Breast Cancer - Influence on Osseous Metastasis. Geburtshilfe und Frauenheilkunde. 2012; 72(5): 385-91.

26. Canon J, Bryant R, Roudier M, Branstetter DG, Dougall WC. RANKL inhibition combined with tamoxifen treatment increases anti-tumor efficacy and prevents tumorinduced bone destruction in an estrogen receptor-positive breast cancer bone metastasis model. Breast Cancer Res Treat. 2012; 135(3): 771-80.

27. Theoleyre S, Wittrant Y, Tat SK, Fortun Y, Redini F, Heymann D. The molecular triad OPG/RANK/RANKL: involvement in the orchestration of pathophysiological bone remodeling. Cytokine Growth Factor Rev. 2004; 15(6): 457-75.

28. Anderson DM, Maraskovsky E, Billingsley WL, Dougall WC, Tometsko ME, Roux ER, Teepe MC, DuBose RF, Cosman D, Galibert L. A homologue of the TNF receptor and its ligand enhance T-cell growth and dendritic-cell function. Nature. 1997; 390 (6656): 175-9.

29. Josson S, Matsuoka Y, Chung LW, Zhau HE, Wang R. Tumor-stroma co-evolution in prostate cancer progression and metastasis. Semin Cell Dev Biol. 2010; 21(1): 26-32.

30. Viereck V, Emons G, Lauck V, Frosch KH, Blaschke S, Gründker C, Hofbauer LC. Bisphosphonates pamidronate and zoledronic acid stimulate osteoprotegerin production by primary human osteoblasts. Biochem Biophys Res Commun. 2002; 291(3): 680-6.

31. Luo XH, Guo LJ, Xie H, Yuan LQ, Wu XP, Zhou HD, Liao EY. Adiponectin stimulates RANKL and inhibits OPG expression in human osteoblasts through the MAPK signaling pathway. J Bone Miner Res. 2006; 21(10): 164856.

32. Neville-Webbe HL, Cross NA, Eaton CL, Nyambo R, Evans CA, Coleman RE, Holen I. Osteoprotegerin (OPG) produced by bone marrow stromal cells protects breast cancer cells from TRAIL-induced apoptosis. Breast Cancer Res Treat. 2004; 86(3): 269-79.

33. Labovsky V, Vallone VB, Martinez LM, Otaegui J, Chasseing NA.Expression of osteoprotegerin, receptor activator of nuclear factor kappa-B ligand, tumor necrosis factor-related apoptosis-inducing ligand, stromal cellderived factor- 1 and their receptors in epithelial metastatic breast cancer cell lines. Cancer Cell Int. 2012; 12(1): 29.

34. Deodhar A, Dore RK, Mandel, Schechtman J, Shergy W, Trapp R, Ory PA, Peterfy CG, Fuerst T, Wang H, Zhou L, Tsuji W, Newmark R. Denosumab-mediated increase in hand bone mineral density associated with decreased progression of bone erosion in rheumatoid arthritis patients. Arthritis care \& research. 2010; 62(4): 569-74.
35. Wright HL, McCarthy HS, Middleton J, Marshall MJ. RANK, RANKL and osteoprotegerin in bone biology and disease. Curr Rev Musculoskelet Med. 2009; 29(1): 56-64.

36. Hofbauer LC, Neubauer A, Heufelder AE. Receptor activator of nuclear factor-kappaB ligand and osteoprotegerin: potential implications for the pathogenesis and treatment of malignant bone diseases. Cancer. 2001; 92(3): 460-70.

37. Emery JG, McDonnell P, Burke MB, Deen KC, Lyn S, Silverman C, Dul E, Appelbaum ER, Eichman C, DiPrinzio R,Dodds RA, James IE, Rosenberg M, et al. Osteoprotegerin is a receptor for the cytotoxic ligand TRAIL. J Biol Chem. 1998; 273(23): 14363-7.

38. Holen I, Croucher PI, Hamdy FC, Eaton CL. Osteoprotegerin (OPG) is a survival factor for human prostate cancer cells. Cancer Res. 2002; 62(6): 1619-23.

39. Shipman CM, Croucher PI. Osteoprotegerin is a soluble decoy receptor for tumor necrosis factor-related apoptosisinducing ligand/Apo2 ligand and can function as a paracrine survival factor for human myeloma cells. Cancer Res. 2003; 63(5): 912-6.

40. Nyambo R, Cross N, Lippitt J, Holen I, Bryden G, Hamdy FC, Eaton CL. Human bone marrow stromal cells protect prostate cancer cells from TRAIL-induced apoptosis. J Bone Miner Res. 2004; 19(10): 1712-21.

41. De Toni EN, Thieme SE, Herbst A, Behrens A, Stieber P, Jung A, Blum H, Göke B, Kolligs FT.OPG is regulated by beta-catenin and mediates resistance to TRAIL-induced apoptosis in colon cancer. Clinical cancer research. 2008; 14(15): 4713-8.

42. Cross SS, Yang Z, Brown NJ, Balasubramanian SP, Evans CA, Woodward JK, Neville-Webbe HL, Lippitt JM, Reed MW,Coleman RE, Holen I. Osteoprotegerin (OPG)--a potential new role in the regulation of endothelial cell phenotype and tumour angiogenesis? International journal of cancer. 2006; 118(8): 1901-8.

43. Weichhaus M, Chung ST, Connelly L. Osteoprotegerin in breast cancer: beyond bone remodeling. Mol Cancer. 2015; 14: 117.

44. Weaver BA, Cleveland DW. Does aneuploidy cause cancer? Curr Opin Cell Biol. 2006; 18(6): 658-67.

45. Suda T, Takahashi N, Udagawa N, Jimi E, Gillespie MT, Martin TJ. Modulation of osteoclast differentiation and function by the new members of the tumor necrosis factor receptor and ligand families. Endocr Rev. 1999; 20(3): 34557.

46. Nakashima T, Kobayashi Y, Yamasaki S, Kawakami A, Eguchi K, Sasaki H, Sakai H. Protein expression and functional difference of membrane-bound and soluble receptor activator of NF-kappaB ligand: modulation of the expression by osteotropic factors and cytokines. Biochem Biophys Res Commun. 2000; 275(3): 768-75.

47. Wiley SR, Schooley K, Smolak PJ, Din WS, Huang CP, Nicholl JK, Sutherland GR, Smith TD, Rauch C, Smith CA, 
et al. Identification and characterization of a new member of the TNF family that induces apoptosis. Immunity. 1995; 3(6): 673-82.

48. Yongchaitrakul T, Manokawinchoke J, Pavasant P. Osteoprotegerin induces osteopontin via syndecan-1 and phosphoinositol 3-kinase/Akt in human periodontal ligament cells. J Periodontal Res. 2009; 44(6): 776-83.

49. Pritzker LB, Scatena M, Giachelli CM. The role of osteoprotegerin and tumor necrosis factor-related apoptosisinducing ligand in human microvascular endothelial cell survival. Mol Biol Cell. 2004; 15(6): 2834-41.

50. Knudsen ST, Foss CH, Poulsen PL, Andersen NH, Mogensen CE, Rasmussen LM. Increased plasma concentrations of osteoprotegerin in type 2 diabetic patients with microvascular complications. Eur J Endocrinol. 2003; 149(1): 39-42.

51. Hofbauer LC, Schoppet M. Clinical implications of the osteoprotegerin/RANKL/RANK system for bone and vascular diseases. JAMA. 2004; 292(4): 490-5.

52. Lane D, Matte I, Laplante C, Garde-Granger P,Rancourt C,Piché A. Osteoprotegerin (OPG) activates integrin, focal adhesion kinase (FAK), and Akt signaling in ovarian cancer cells to attenuate TRAIL-induced apoptosis. J Ovarian Res. 2013; 6(1): 82.

53. McGonigle JS, Giachelli CM, Scatena M. Osteoprotegerin and RANKL differentially regulate angiogenesis and endothelial cell function. Angiogenesis. 2009; 12(1): 35-46.

54. Benslimane-Ahmim Z, Heymann D, Dizier B, Lokajczyk A, Brion R, Laurendeau I, Bièche I, Smadja DM, GalyFauroux I,Colliec-Jouault S, Fischer AM, Boisson-Vidal C. Osteoprotegerin, a new actor in vasculogenesis, stimulates endothelial colony-forming cells properties. J Thromb Haemost. 2011; 9(4): 834-43.

55. Benslimane-Ahmim Z, Poirier F, Delomenie C, Lokajczyk A, Grelac F, Galy-Fauroux I, Mohamedi A, Fischer AM,Heymann D, Lutomski D, Boisson-Vidal C. Mechanistic study of the proangiogenic effect of osteoprotegerin. Angiogenesis. 2013; 16(3): 575-93.

56. Reid PE, Brown NJ, Holen I. Breast cancer cells stimulate osteoprotegerin (OPG) production by endothelial cells through direct cell contact. Mol Cancer 2009; 8: 49.

57. Bugler B, Caizergues-Ferrer M, Bouche G, Bourbon H, Amalric F. Detection and localization of a class of proteins immunologically related to a $100-\mathrm{kDa}$ nucleolar protein. Eur J Biochem. 1982; 128(2-3): 475-80.

58. Erard MS, Belenguer P, Caizergues-Ferrer M, Pantaloni A, Amalric F. A major nucleolar protein, nucleolin, induces chromatin decondensation by binding to histone H1. Eur J Biochem 1988; 175(3): 525-30.

59. Escande-Geraud ML, Azum MC, Tichadou JL, Gas N. Correlation between rDNA transcription and distribution of a $100 \mathrm{kD}$ nucleolar protein in CHO cells. Exp Cell Res. 1985; 161(2): 353-63.

60. Chen X, Kube DM, Cooper MJ, Davis PB. Cell surface nucleolin serves as receptor for DNA nanoparticles composed of pegylated polylysine and DNA. Molecular therapy. 2008; 16(2): 333-42.

61. Hovanessian AG, Soundaramourty C, El Khoury D, Nondier I,Svab J,Krust B. Surface expressed nucleolin is constantly induced in tumor cells to mediate calciumdependent ligand internalization. PloS one. 2010; 5(12): e15787.

62. Fogal V, Sugahara KN, Ruoslahti E, Christian S. Cell surface nucleolin antagonist causes endothelial cell apoptosis and normalization of tumor vasculature. Angiogenesis. 2009; 12(1): 91-100.

63. Christian S, Pilch J, Akerman ME, Porkka K, Laakkonen $\mathrm{P}$, Ruoslahti E. Nucleolin expressed at the cell surface is a marker of endothelial cells in angiogenic blood vessels. J Cell Biol. 2003; 163(4): 871-8.

64. Semenkovich CF, Ostlund RE, Jr., Olson MO, Yang JW. A protein partially expressed on the surface of HepG2 cells that binds lipoproteins specifically is nucleolin. Biochemistry. 1990; 29(41): 9708-13.

65. Parzych K, Chinn TM, Chen Z, Loaiza S, Porsch F, Valbuena GN, Kleijnen MF, Karadimitris A, Gentleman E, Keun HC, Auner HW. Inadequate fine-tuning of protein synthesis and failure of amino acid homeostasis following inhibition of the ATPase VCP/p97. Cell death \& disease. 2015; 6: e2031.

66. Zhu WW, Kang L, Gao YP, Hei Y, Dong J, Liu Y, Xiao LH, Yang G. Expression level of valosin containing protein is associated with prognosis of primary orbital MALT lymphoma. Asian Pacific journal of cancer prevention : APJCP. 2013; 14(11): 6439-43.

67. Suburu J, Shi L, Wu J, Wang S, Samuel M, Thomas MJ, Kock ND, Yang G, Kridel S, Chen YQ.Fatty acid synthase is required for mammary gland development and milk production during lactation. American journal of physiology Endocrinology and metabolism. 2014; 306(10): E1132-43.

68. Sangeetha M, Deepa PR, Rishi P, Khetan V, Krishnakumar S. Global gene deregulations in FASN silenced retinoblastoma cancer cells: molecular and clinicopathological correlations. Journal of cellular biochemistry. 2015; 116(11): 2676-94.

69. Zaytseva YY, Elliott VA, Rychahou P, Mustain WC, Kim JT, Valentino J, Gao T, O’Connor KL, Neltner JM, Lee EY, Weiss HL, Evers BM.Cancer cell-associated fatty acid synthase activates endothelial cells and promotes angiogenesis in colorectal cancer. Carcinogenesis. 2014; 35(6): 1341-51.

70. Chandran K, Goswami S, Sharma-Walia N. Implications of a peroxisome proliferator-activated receptor alpha (PPARalpha) ligand clofibrate in breast cancer. Oncotarget. 2015; doi: 10.18632/oncotarget.6402.

71. Mundy GR. Metastasis to bone: causes, consequences and therapeutic opportunities. Nat Rev Cancer. 2002; 2(8): 58493. 
72. Zhang J, Dai J, Qi Y, Lin DL, Smith P, Strayhorn C, Mizokami A, Fu Z, Westman J, Keller ET. Osteoprotegerin inhibits prostate cancer-induced osteoclastogenesis and prevents prostate tumor growth in the bone. J Clin Invest. 2001; 107(10): 1235-44.

73. Corey E, Brown LG, Kiefer JA, Quinn JE, Pitts TE, Blair $\mathrm{JM}$, Vessella RL. Osteoprotegerin in prostate cancer bone metastasis. Cancer Res 2005; 65(5): 1710-8.

74. Eaton CL, Wells JM, Holen I, Croucher PI, Hamdy FC. Serum osteoprotegerin (OPG) levels are associated with disease progression and response to androgen ablation in patients with prostate cancer. The Prostate. 2004; 59(3): 304-10.

75. Penno H, Silfversward CJ, Frost A, Brändström H, Nilsson $\mathrm{O}$, Ljunggren $\mathrm{O}$. Osteoprotegerin secretion from prostate cancer is stimulated by cytokines, in vitro. Biochem Biophys Res Commun. 2002; 293(1): 451-5.

76. Oliver JL, Alexander MP, Norrod AG, Norrod AG, Mullins IM, Mullins DW. Differential expression and tumor necrosis factor-mediated regulation of TNFRSF11b/ osteoprotegerin production by human melanomas. Pigment Cell Melanoma Res. 2013; 26(4): 571-9.

77. Pettersen I, Bakkelund W, Smedsrod B, Sveinbjornsson B. Osteoprotegerin is expressed in colon carcinoma cells. Anticancer Res. 2005; 25(6B): 3809-16.

78. Tsukamoto S, Ishikawa T, Iida S, Ishiguro M, Mogushi K, Mizushima H, Uetake H, Tanaka H, Sugihara K. Clinical significance of osteoprotegerin expression in human colorectal cancer. Clinical cancer research. 2011; 17(8): 2444-50.

79. Ito R, Nakayama H, Yoshida K, Kuraoka K, Motoshita J, Oda N, Oue N, Yasui W. Expression of osteoprotegerin correlates with aggressiveness and poor prognosis of gastric carcinoma. Virchows Arch. 2003; 443(2): 146-51.

80. Mizutani Y, Matsubara H, Yamamoto K, Nan Li Y, Mikami K, Okihara K, Kawauchi A, Bonavida B, Miki T. Prognostic significance of serum osteoprotegerin levels in patients with bladder carcinoma. Cancer 2004; 101(8): 1794-802.

81. Shi W, Qiu W, Wang W, Zhou X, Zhong X, Tian G, Deng A. Osteoprotegerin is up-regulated in pancreatic cancers and correlates with cancer-associated new-onset diabetes. Biosci Trends. 2014; 8(6): 322-6.

82. Toffoli B, Bernardi S, Candido R, Sabato N, Carretta R, Corallini F, Secchiero P, Zauli G, Fabris B. Osteoprotegerin induces morphological and functional alterations in mouse pancreatic islets. Mol Cell Endocrinol. 2011; 331(1): 13642.

83. Bakry R, El-Sayed MI, Hamza HM, Hassan KH. Pretreatment levels of serum osteoprotegerin and p53 protein and urine telomerase as prognostic factors affecting survival in Egyptian bladder cancer patients. Oncol Lett. 2016; 11(1): 823-30.

84. Serdaroglu Beyazal M, Erdogan T, Turkyilmaz AK,
Devrimsel G, Cüre MC, Beyazal M, Sahin I. Relationship of serum osteoprotegerin with arterial stiffness, preclinical atherosclerosis, and disease activity in patients with ankylosing spondylitis. Clin Rheumatol. 2016.

85. O’Regan N, Moxon C, Gegenbauer K, O’Sullivan JM, Chion A, Smith OP, Preston RJ, Brophy TM, Craig AG, O'Donnell JS1. Marked elevation in plasma osteoprotegerin constitutes an early and consistent feature of cerebral malaria. Thromb Haemost. 2016; 115(4):773-80.

86. Omland T, Ueland T, Jansson AM, Persson A, Karlsson T, Smith C, Herlitz J, Aukrust P, Hartford M, Caidahl K. Circulating osteoprotegerin levels and long-term prognosis in patients with acute coronary syndromes. J Am Coll Cardiol. 2008; 51(6): 627-33.

87. Golledge J, McCann M, Mangan S, Lam A, Karan M. Osteoprotegerin and osteopontin are expressed at high concentrations within symptomatic carotid atherosclerosis. Stroke. 2004; 35(7): 1636-41.

88. Abedin M, Omland T, Ueland T, Khera A, Aukrust P, Murphy SA, Jain T, Gruntmanis U, McGuire DK, de Lemos JA. Relation of osteoprotegerin to coronary calcium and aortic plaque (from the Dallas Heart Study). Am J Cardiol. 2007; 99(4): 513-8.

89. Ayina Ayina CN, Sobngwi E, Essouma M, Noubiap JJ, Boudou P, Etoundi Ngoa LS6, Gautier JF7. Osteoprotegerin in relation to insulin resistance and blood lipids in subSaharan African women with and without abdominal obesity. Diabetol Metab Syndr. 2015; 7: 47.

90. Ueland T, Kjekshus J, Froland SS, Omland T, Squire IB, Gullestad L, Dickstein K, Aukrust P. Plasma levels of soluble tumor necrosis factor receptor type I during the acute phase following complicated myocardial infarction predicts survival in high-risk patients. J Am Coll Cardiol. 2005; 46(11): 2018-21.

91. Jensen JK, Ueland T, Atar D, Gullestad L, Mickley H, Aukrust P, Januzzi JL. Osteoprotegerin concentrations and prognosis in acute ischaemic stroke. J Intern Med. 2010; 267(4): 410-7.

92. Ney JT, Juhasz-Boess I, Gruenhage F, Graeber S, Bohle RM, Pfreundschuh M, Solomayer EF, Assmann G. Genetic polymorphism of the OPG gene associated with breast cancer. BMC cancer. 2013; 13: 40.

93. Omar HS, Shaker OG, Nassar YH, Marzouk SA, ElMarzouky MS. The association between RANKL and Osteoprotegerin gene polymorphisms with breast cancer. Mol Cell Biochem. 2015; 403(1-2): 219-29.

94. Narita N, Yuasa T, Tsuchiya N, Kumazawa T, Narita S, Inoue T, Ma Z, Saito M, Horikawa Y, Satoh S, Ogawa O, Habuchi T. A genetic polymorphism of the osteoprotegerin gene is associated with an increased risk of advanced prostate cancer. BMC cancer. 2008; 8: 224.

95. Sonmez M, Kazaz N, Yucel B, Topbas M, Ucar F. C950T and $\mathrm{C} 1181 \mathrm{G}$ osteoprotegerin gene polymorphisms in 
myeloma bone disease. Hematology. 2014; 19(4): 213-6.

96. Bonfa AC, Seguro LP, Caparbo V, Bonfá E, Pereira RM. RANKL and OPG gene polymorphisms: associations with vertebral fractures and bone mineral density in premenopausal systemic lupus erythematosus. Osteoporos Int. 2015; 26(5): 1563-71.

97. Krajcovicova V, Omelka R, Durisová J, Martiniakova M, Galbavy D, Bauerova M. The effect of A163G polymorphism in the osteoprotegerin gene on osteoporosis related traits in Slovak postmenopausal women. Anthropologischer Anzeiger. 2015; 72(3): 311-9.

98. Yang Y, Liu X, Jia J, Bai Y, Dai L, Wang T, Zhou B, Zhang L, Zhou R. Role of osteoprotegerin gene variants in early-onset severe pre-eclampsia. Journal of obstetrics and gynaecology research. 2015; 41(3): 334-42.

99. Kwan JS, Hsu YH, Cheung CL, Dupuis J, Saint-Pierre A, Eriksson J, Handelman SK, Aragaki A, Karasik D,Pramstaller PP, Kooperberg C, Lacroix AZ, Larson $\mathrm{MG}$, et al. Meta-analysis of genome-wide association studies identifies two loci associated with circulating osteoprotegerin levels. Human molecular genetics. 2014; 23(24): 6684-93.
100. Widschwendter M, Burnell M, Fraser L, Rosenthal AN, Philpott S, Reisel D, Dubeau L, Cline M, Pan Y, Yi PC, Gareth Evans D, Jacobs IJ, Menon U, et al. Osteoprotegerin (OPG), The Endogenous Inhibitor of Receptor Activator of NF-kappaB Ligand (RANKL), is Dysregulated in BRCA Mutation Carriers. EBioMedicine. 2015; 2(10): 1331-9.

101. Chanda D, Isayeva T, Kumar S, Siegal GP, Szafran AA, Zinn KR, Reddy VV, Ponnazhagan S. Systemic osteoprotegerin gene therapy restores tumor-induced bone loss in a therapeutic model of breast cancer bone metastasis. Molecular therapy. 2008; 16(5): 871-8. 